\title{
TAX POLICY EFFICIENCY ISSES IN THE MINING SECTOR (THEORETICAL APPROACH)
}

\author{
Armen Tshughuryan', Sveta Muradyan² \\ ${ }^{1}$ Professor of Northern University, Doctor of Economics Scenes \\ e-mail Jarmen1@yandex.ru \\ ${ }^{2}$ Postgraduate Student, Northern University of Yerevan, Yerevan, Armenia, \\ e-mail sveta.muradyan@gmail.com
}

\begin{abstract}
A tight tax policy that is likewise fitting for the financial circumstance is a significant essential for accomplishing reasonable financial development. The examination point - to suggest theoretical ways for improving methodology for assessment efficiency of tax policy in mining sector. In theory mainly the effectiveness of tax policy is viewed from the point of view of tax collection. The article attempts to present a new theoretical approach for assessing the effectiveness of tax policy, taking into account the expectations of not only the government, but also other stakeholders in the mining industry (investors, community residents, businessmen, employees), which are having different expectations, concerning collected taxes and expending public resources. In this regard, a new theoretical methodology to assessing the effectiveness of tax policy is proposed, based on the feedback information available among the mining stakeholders.
\end{abstract}

Keywords: fiscal policy, tax burden, mining production, taxation. JEL code: E62, H21.

\section{Introduction}

Tax policy is a concept that refers to public financial administration, which includes both tax revenue and expenditure policies, debt management policy and the use of other instruments relating to public finances that are at the disposal of the government. Using this set of instruments, the government can make adjustments to its spending and tax policies to monitor the national economy and direct it towards the desired pathway. Therefore, a tight fiscal policy that is also appropriate for the economic situation is a very important prerequisite for achieving sustainable economic growth and price stability (Harutyunyan, T., 2013).

Research novelty: Although many researchers have made a significant contribution in development of tax policy (Otto, J, 2005, Harutyunyan, 2013, Хеллер, 2009, Игонина, 2014), however, the several theoretical points is necessitating for development, concerning to assessment of taxation efficiency in mining sector.

Consequently, a new methodology is suggested to the assessment of tax policy efficiency of the mining industry, implementing appropriate information flows based on feed back indicators from external and internal beneficiaries of mining industry. 
Research aim: the research aim is to examine the theoretical ways of improving methodology of effectiveness of the tax policy in mining production.

\section{Research tasks:}

Specific research tasks:

1) give insight into the macroeconomic role of tax policy;

2) describe the approach to tax policy efficiency easement in the mining sector;

3) develop a new theoretical approach to the tax policy efficiency interpretation of the mining industry.

Methods used in the research: literature reviewing, theoretical aspect analysis and logical construction.

Research hypothesis: the use of theoretical approaches to improving fiscal policy effectiveness, taxation in the mining industry to be associated with the main functions of taxation, taking into account tax collections, controlling, and public financial sources reasonable distribution's among beneficiaries.

\section{Theoretical review and discussion}

The assessment of the effectiveness of fiscal policy was in the focus of economists' attention in the 1930s, when during the Great Depression it became clear that the state could achieve macroeconomic regimes due to flexible collection of taxes and budget expenditure directions, mitigating unemployment by activating the economy through government industrial procurement, public spending services, and differentiated tax rates (Арутунян, 2013). Later, the Keynes theory once again underlined the regulatory role of the government in the macroeconomic environment (Кейсн, 1936, Atkinson, A. B, 2014). Theories of discretionary fiscal policy, followed by the Keynesian theory, are being analysed when different estimates are given to the government's taxation goals, not only to the formation of public spending resources, but also to the government and not to private business by the activation of production and the regulation of economic growth (Игонина, 2014). Such approaches to fiscal policy give their considerable results in the macroeconomic realm when taxation trends are interconnected with GDP growth, business capitalization, and public debt management (Otto, 2006). However, problems with such studies in the branch field are not deeply entrenched. Instead, the effectiveness of fiscal policy outcomes is more likely to give rise to interpretations from the "bottom", i.e. the beneficiaries of the fraudulent activity, rather than from the "top" (by the state) (Хеллер, 2009). In addition, many problems of "bottom" development are associated not only with differentiation determined by 
budget potential, but also with the efficiency and effectiveness of budget expenditures. The current problem of territorial budgets is not an insufficient amount of budgetary resources as its inefficient use. In these case, the role of budget regulation of "bottom" development, based on increasing the financial and resource basis for the development of the territory, is determined by both factors of budget revenue growth and factors of rationalization of budget expenditures (L.V. Perekrestova, E.B. Dyakova, 2011).

Such a situation is especially evident in the mining industry, where organizations pay additional environmental taxes along with the direct and indirect taxes on the business, while the surrounding population performs auxiliary socio-economic functions (Henderson Global Investors, 2005). Therefore, in this regard, the basis of the assessment of the effectiveness of fiscal policy in the sector, according to the authors, should be the expectations of tax-paying mining organizations and community-based population taxation (Кучеров И.И., 2008).

In this regard, the concept of effective fiscal policy in the mining industry is suggested to be considered from the point of view of the efficiency of taxation and the provision of feedback on socio-economic expectations of the population (see Figure 1). At the same time, the proposed concept of taxable real estates of mining organizations as well as the estimates of the payment return are considered key.

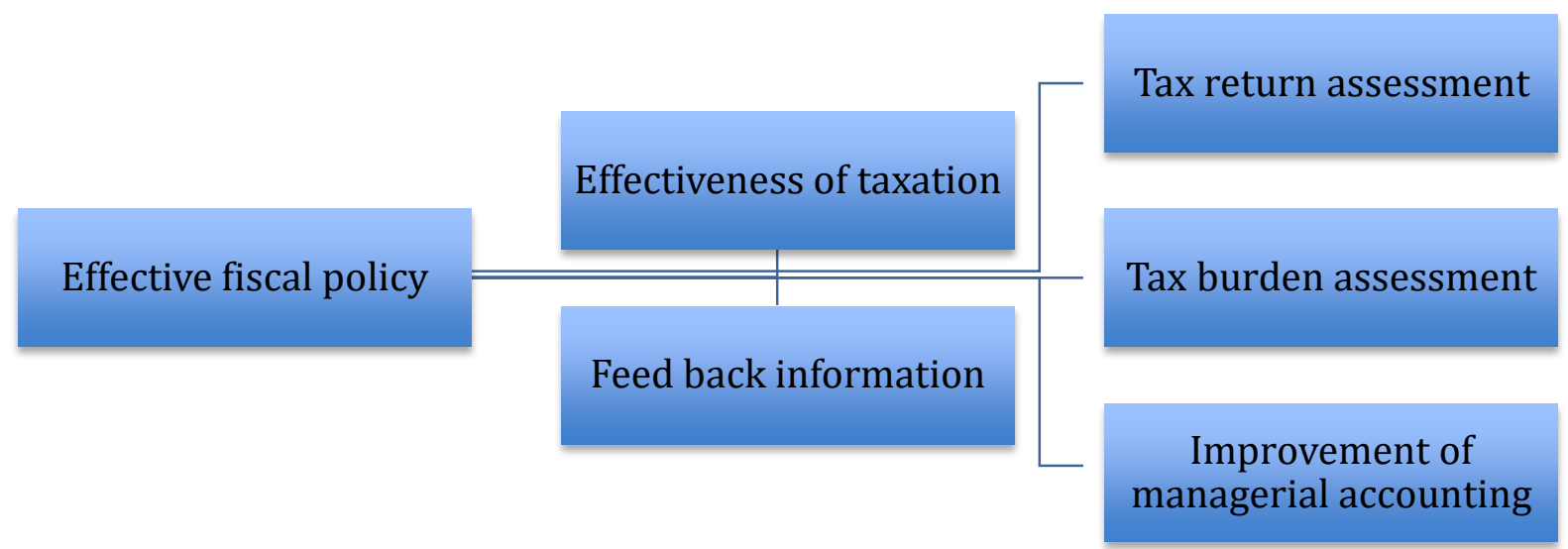

Fig.1 Proposed Ways to Formulate a Tax Policy Concept in the Mining Industry (created by the author)

\section{Research results}

In theory there is a problem of establishing a general index of tax burden for mining companies, which will be able to assess the effectiveness of the taxation. As a rule, the most commonly used index of tax burden at macroeconomic level is the ratio of collected taxes/GDP (Harutyunyan, 
2013). Based on this approach, the author propose to a taxpayer - a mining organization - to introduce a general index of tax burden on the total amount of revenue/sales income from the state budget. However, the authors believe that the fiscal efficiency concept is not sufficient to justify the tax burden. It also emphasizes the significance of the taxpayer's assessment. Taxpayers are interested in determining the extent to which the state supports their sustainable functioning and development.

Paying taxes by utilizing environmental benefits, mining companies in their turn have state-of-the-art facilities. At the same time, these expectations can be interpreted from the point of view of government-supported programmes for socio-economic development of the business and community (Otto, 2005). The state should be interested and why not often, as co-sponsors, introduce non-hazardous and up-to-date technologies in mining, assist organizations in implementing international marketing of metal concentrates, carry out large-scale work on preventing ecological damage, which taxpayers are unable to implement.

On the other hand, the community-based adjacent community of mining companies also has expectations from the state that address socio-economic actions that relate to the improvement of community infrastructure, healthcare arrangements, clearance of industrial wastes and so on.

Consequently, if the actual implementation of the expectations of businessmen and population can be assessed on the scale of $0-100 \%$, the effectiveness of taxation of the mining industry, i.e. the actual rate of tax redistribution collected at the level of $1 \%$ of the tax burden, could be calculated as follows:

where:

$$
\mathrm{TE}=\mathrm{EG} / \mathrm{TB}
$$

$\mathrm{TE}$ - tax return ratio (\%)

EG - is a state-owned mining industry's actual degree of support for expectations (\%)

TB - tax burden for mining companies

Thus, if mining companies have sold 25 billion Armenian Dram (AMD) worth of goods in the analysed period, by paying 2 billion AMD for direct, indirect taxes, environmental and utilization payments, the tax burden will be presented at micro level by $8 \%(2 / 25 \times 100)$. In the same period, if the mining companies expect the state to support different segments of the sector's development, only $72 \%$ have been implemented, so the efficiency of the taxation business will be estimated by the business world at $9 \%(72 / 8)$. And if the expectations of socio-economic support by the community's 
population during this same period were only $40 \%$, then the taxpayer remittance would decline and would be estimated at 5\% (40/8).

Thus, the proposed "tax return ratio" in the mining industry suggests the effectiveness of fiscal policy, as it summarizes the fiscal performance of the state on the one hand and on the other shows the areas of taxation and the actual return on the use of the targeted direction. At the same time, this information requirement first of all considers stakeholders in the mining industry (investors, organization managers, community governing bodies, population) for which effective fiscal policies, according to the authors, should be accountable, and conversion connection (see Figure 1). It is important to provide feedback to all stakeholders related to the development of the mining industry, thereby considering taxation and accountability as one of the key principles of fiscal policy implementation. In doing so, the information security requirement of the tax policy effectiveness in the sector is formulated as a "bottom" whereby beneficiaries of the mining industry regularly submit proposals to the state for fiscal policy improvements (see Figure 2).

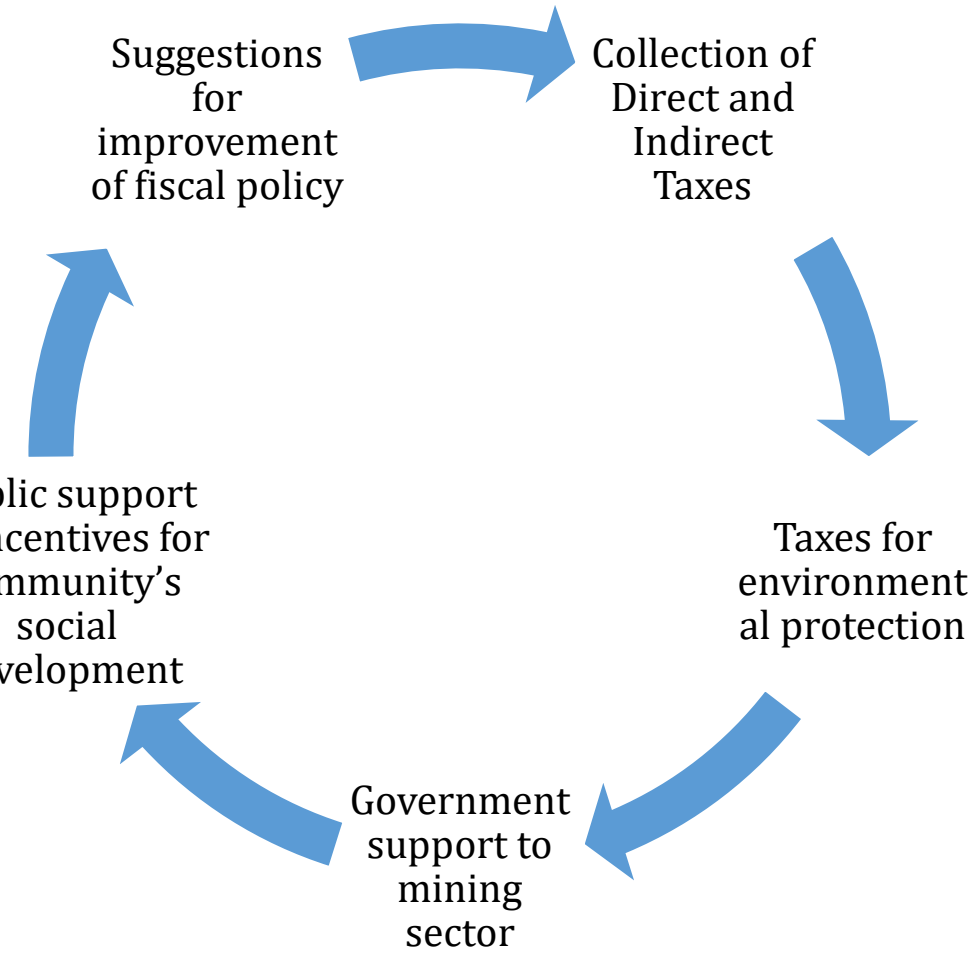

\section{Fig.2 The role of information feedback in making tax policy in the context of policy reforms (created by the author)}

In this regard, it is important to improve the financial and managerial accounting information system in mining organizations so that beneficiaries in the field receive periodic information not only about tax liabilities, but also 
about the directions, dimensions and actual rewards of redistribution of financial resources formed from taxation.

\section{Conclusions and suggestions}

There are some information problems when evaluating the effectiveness of the tax policy in the mining industry. These issues mainly arise in the context of providing "information feedback" on taxation. The new approach to the fiscal policy of the mining industry proposed by the author will provide an opportunity.

Suggestions to fiscal policy makers: the first suggestion concerns improving fiscal functions from the "bottom", i.e. beneficiaries included in the taxation area. In this case, the representatives of the business sector, as well as community self-governance bodies, can account for tax compliance and redistribution, can give general assessments on the sectoral effectiveness of fiscal functions; secondly, measuring the tax burden on the mining sector by not only providing estimates for fiscal policy, but also doing a comparative analysis of such assessments from the view of the social and economic expectations of business beneficiaries and community populations; third, provide information feedback from all stakeholders involved in the development of the mining industry, thereby assuming accountability as one of the key principles of fiscal policy implementation.

\section{References}

1. Harttyunyan, T. (2013). Business Environment and the Comparative Characteristics of Taxes in the Republic of Armenia. Armenia, Finance and Economics, \#11-12 (161162), pp. 44-46.

2. Арутунян, Т. (2013). Направление налоговых реформ и проблемы оценки налоговой нагрузки в РА. Известия аграрной науки, том 11, \#3, стр. 93-98.

3. Кучеров, И.И. (2008). Новый концептуальный подход к определению налога. Финансовое право, № 1, стр. 32-35.

4. Игнонина, Л. (2014). Конкурентоспособность национальной экономики: инновационные императивы и финансовые регуляторы. Экономический анализ: теория и практика, № 7. С. 12-20.

5. Игониина, Л. (2014). Воздействие фискальной и монетарной политики на развитие экономики и социальной сферы. Финансы и кредит, № 15. стр., 3745.

6. Кейсн, Дж. (1936). Общая теория занятости, процента и денег.

7. Хеллер, П. (2009). Фискальное пространство - что это такое и как его получить? Финансы и развитие, Июнь. С. 32-33.

8. Ankinson, A. (2014). Optimal Taxation and the Direct Versus Indirect Tax Controversy.. Can. J. Econ, p. 590. 
9. Increase fiscal space of territory on the basis of effective budgetary adjustment/ L.V. Perekrestova, E.B. Dyakova. National interests: priorities and security. 2011. - № 30 (123). - august. - P. 21-28.

10. Otto, J. (2006). Mining Royalties: a global study and their impact on investment, government and civil society. The World Bank, $148 \mathrm{p}$.

11. Otto, J. (2005). Mining Taxation. Uunpublished presentation to World bank seminar, Washington DC. - p. 56-61

12. Fiscal space: the analysis, an estimation and a choice of priorities of budgeted expenses, on December, 2-3nd, 2007, Brunei: materials of the international seminar. Henderson Global Investors (2005). Responsible Tax. Henderson Global Investors ltd., london, UK, 2005, - p. 28-32 